Research Article

Bülent Aktaş*, Mehmet Toprak, Adnan Çalık, and Ali Tekgüler

\title{
Effect of pack-boriding on the tribological behavior of Hardox 450 and HiTuf Steels
}

https://doi.org/10.1515/rams-2020-0030

Received Feb 13, 2020; accepted May 05, 2020

\begin{abstract}
In this study, Hardox 450 and HiTuf steels were boronized by pack-boriding method at 800,900 , and $1000^{\circ} \mathrm{C}$ for $5 \mathrm{~h}$. The phases, microstructure, hardness, and wear behavior of boride layers formed on the surface of samples were investigated using XRD, SEM, MicroVickers hardness testers, and a pin-on-disc tribotester, respectively. XRD analysis showed that both $\mathrm{FeB}$ and $\mathrm{Fe}_{2} \mathrm{~B}$ phases were formed in the borided area of Hardox 450 steel, but only $\mathrm{Fe}_{2} \mathrm{~B}$ phase occurred in the boride layer of the HiTuf steel. Micro-Vickers hardness results indicated that the hardness values of the boride layer decreased from the column-shaped structure to towards the matrix in both of Hardox 450 and HiTuf steels. Furthermore, the wear test results showed the coefficients of friction (COF) decreased significantly in the borided samples. The COF of the unborided Hardox 450 steel was reduced considerably from 0.29 to 0.02 by boriding treatment. Similarly, the COF of unborided HiTuf steel was significantly diminished from 0.16 to 0.04 by boriding treatment. In conclusion, the results of this study have indicated that the wear resistance of Hardox 450 and HiTuf steels can be improved by packboriding.
\end{abstract}

Keywords: Hardox 450 and HiTuf steel, Pack-boriding, Friction, Wear

\section{Introduction}

Hardox steels are generally classified as low alloy steels containing low amounts of boron. Hardox steels are mostly

\footnotetext{
${ }^{\star}$ Corresponding Author: Bülent Aktaş: Harran University, Mechanical Engineering Department, Şanlıurfa, Turkey; Email: baktas@harran.edu.tr

Mehmet Toprak: Harran University, Mechanical Engineering Department, Şanlıurfa, Turkey

Adnan Çalık: Isparta University of Applied Sciences, Mechanical Engineering Department, Isparta, Turkey

Ali Tekgüler: Ondokuz Mayıs University, Machinery and Metal Technology, Samsun, Turkey
}

preferred in the marine and mining industry, heavy construction equipment, grinders, and conveyor applications due to their high strength, good formability, and weldability $[1,2]$. However, the tribological performance of these steels can be inadequate in some engineering applications at room temperature and/or high operating temperatures with abrasive environments [2]. Therefore, surface treatment is required to overcome this disadvantage. Material surfaces can be improved by various techniques such as plasma-assisted thermochemical processes and thin film coatings to increase the properties of steels such as wear, corrosion, and resistance at room temperature and/or high temperatures [3-6].

The creation of iron borides on the surface of the steels is one of the most well known boriding processes [7]. Boriding is known to be an effective method to significantly increase the surface hardness and abrasion resistance of metals, non-ferrous, superalloys, and even cermets [8-11]. The boriding process is a chemical heat treatment that aims to diffuse boron atoms to the sample surface and forms borides with base metal [12-15]. Borides formed by the boriding process improve the tribological behavior of substrate steel [16]. Iron borides are formed ( $\mathrm{FeB}, \mathrm{Fe}_{2} \mathrm{~B}$ ) by the diffusion of the boron element into the steel, and temperature and time of the boriding process determines the thickness of the boride layer [17-19]. It has a column-shaped crystal structure positioned in the direction of diffusion in both layers [20]. Boriding process has been shown to have outstanding tribological properties compared to carburized and nitrided steel as a surface hardening method in the industry [21-26]. Boronized iron and steel surfaces are of high hardness, excellent wear, good corrosion, and strong chemical stability [27, 28].

There are only a few articles on boriding of Hardox steels in the literature. Kapcinska-Popowska et al. studied the effect of diffusion boriding and laser boriding on microstructure, microhardness, and corrosion resistance of Hardox 450 steel. They reported that the hardness and corrosion resistance of Hardox 450 steel was increased by laser and diffusion boriding [29]. In another study of the same authors, they investigated the effect of laser and diffusion boriding of Hardox 450 steel on the microstructure, hardness and wear resistance, and informed that the wear

ð Open Access. (c) 2020 B. Aktaş et al., published by De Gruyter. (cc) BY This work is licensed under the Creative Commons Attribution 4.0 License 
Table 1: The chemical compositions of Hardox 450 and HiTuf steels (wt.\%).

\begin{tabular}{lccccccccc}
\hline Samples & C & Si & Mn & P & S & Cr & Ni & Mo & B \\
\hline Hardox 450 & 0.26 & 0.70 & 1.60 & 0.025 & 0.010 & 1.40 & 1.50 & 0.60 & 0.005 \\
Hardox HiTuf & 0.20 & 0.60 & 1.60 & 0.050 & 0.020 & 0.70 & 2.0 & 0.70 & 0.005 \\
\hline
\end{tabular}

resistance and hardness were improved by laser and diffusion boriding [30]. Mindivan studied the effects of combined diffusion treatments on wear behavior of Hardox 400 steel. It was reported that the hardness and wear resistance of Hardox 400 steel significantly increased after boronizing the nitrided layer [2]. Yllmaz et al. studied the boronizing effect on the radiation shielding properties of Hardox 450 and Hardox HiTuf steels. It was notified that Hardox 450 and Hardox HiTuf steels shielded gamma radiations more effectively with the boronizing process, and also the increasing the boronizing temperature increased the effect of the radiation shielding [10].

Although many surface treatments, such as boriding, have been developed to improve the wear performance of iron and alloys, only a few studies in the literature have focused on determining the wear behavior of the borided hardox steels and the wear mechanisms involved. Therefore, in this study, we aim to investigate the effect of boriding temperature on the structure, hardness, friction, and wear behavior at room temperature $\left(25^{\circ} \mathrm{C}\right)$ conditions of the boride layer formed on the surface of Hardox 450 and HiTuf steels.

\section{Materials and experimental procedures}

In this study, the chemical compositions of Hardox 450 and HiTuf steels used for the boronizing process are listed in Table 1. Before the boronizing process, the test samples (three samples for each process) were cut into $19 \times 19 \times 10$ $\mathrm{mm}^{3}$ dimensions using a laser. Sample surfaces were then ground using $\mathrm{SiC}$ papers (300 to 800 grit) to remove impurities and oxide layers on the surface and obtain smoother surfaces. After grinding, the samples were washed with methyl alcohol. The samples were packed in commercial Ekabor-I boron source and ferrosilicon as an activator in the boronizing process. The boronizing treatment was carried out at 800,900 , and $1000^{\circ} \mathrm{C}$ for $5 \mathrm{~h}$ under atmospheric pressure. After the heat treatment, the boronized samples were removed from the furnace and cooled to room temperature in the open air. After the boronizing process, the cross-sectional samples were embedded in the resin, ground on 300, 600, 800, 1000, and 1200 grit SiC sandpaper and polished on 3 and $1 \mu \mathrm{m}$ diamond solution for studying microstructures and microhardness. After polishing, the samples were etched in a solution of $5 \% \mathrm{HNO}_{3}+$ 95\% Ethanol for $120 \mathrm{~s}$ to reveal microstructural details.

The presence of borides on the surface of the boronized Hardox 450 and HiTuf steels was determined using the X-ray diffractometer (Rigaku-Dmax 2000) with $\mathrm{CuK}_{\alpha}$ radiation. Metallographic sections were prepared to observe morphological details using optical microscopy and scanning electron microscopy (SEM, ZEISS EVO 50) equipped with energy-dispersive X-ray spectroscopy (EDX). Microhardness of the boride layers was performed by a Micro-Vickers tester using $100 \mathrm{~g}$ load for $15 \mathrm{~s}$. The three indentations were made on each coating layer. Dry sliding wear tests were performed at room temperature $\left(25^{\circ} \mathrm{C}\right)$ on a pin-on-disc tribometer (TRD Engineering, Turkey). Dry sliding wear tests of borided and unborided Hardox 450 and HiTuf steel samples were carried out under $30 \mathrm{~N}$ load with a sliding velocity of $0.2 \mathrm{~m} / \mathrm{s}$ for $500 \mathrm{~m}$ of sliding distance against a high-speed steel (HSS) pin (hardness 66 HRC). Before and after the wear tests, the surfaces of the test specimens and pin were cleaned with methanol. Before and after wear, weights of the samples were measured using AUW-D Shimadzu semi-micro balance (0.01 $\mathrm{mg})$. Specific wear rates (W) of the samples were calculated using the Equation (1). The densities of $\mathrm{FeB}$ and $\mathrm{Fe}_{2} \mathrm{~B}$ phases respectively were used as 6.75 and $7.43 \mathrm{~g} / \mathrm{cm}^{3}$ to determine the specific wear rates [7].

$$
W=\frac{\Delta W}{L \cdot \rho . F}
$$

Where $W$ is specific wear rate $\left(\mathrm{mm}^{3} / \mathrm{Nm}\right), \Delta W$ weight loss of the sample (mg), $L$ sliding distance $(\mathrm{m}), \rho$ experimental density of the sample $\left(\mathrm{g} / \mathrm{cm}^{3}\right)$, and $F$ is normal load $(\mathrm{N})$. After the wear test, worn surfaces were investigated using SEM and EDX.

\section{Results and discussion}

Optical microscope microstructure images of Hardox 450 and HiTuf steels borided at 800,900 , and $1000^{\circ} \mathrm{C}$ for $5 \mathrm{~h}$ are illustrated in Figure 1. Boride layers have formed on 
the surfaces of both Hardox 450 and HiTuf steels by the boriding process. The boride layers forming on the surfaces of the samples consist of crystals having a columnshape from the surface towards the base material. Also, the diffusion depth of the boride layer on the surface of the samples enhances with the increasing of boriding temperature (Figure 1).



Figure 1: Optical microstructures of Hardox 450 and HiTuf steels borided at 800,900 , and $1000^{\circ} \mathrm{C}$.

The effect of boriding temperature on boride layer depth in Hardox 450 and HiTuf steels is shown in Figure 2. The boride layer thickness of Hardox 450 has increased from $68 \mu \mathrm{m}$ at $800^{\circ} \mathrm{C}$ to $344 \mu \mathrm{m}$ at $1000^{\circ} \mathrm{C}$. The boride layer thickness of HiTuf steel has enhanced from $61 \mu \mathrm{m}$ at $800^{\circ} \mathrm{C}$ to $337 \mu \mathrm{m}$ at $1000^{\circ} \mathrm{C}$. The boride layer thickness depends on the concentration of alloying elements as well as treatment temperature and time. Many researchers have reported that the boride layer of low alloy steels borided by thermochemical methods exhibits a column-shaped structure $[7,12,31$. The column-shaped structure is characteristic of the boride layer. The amount of column-shaped transition between the coating and the base material depends on the processing temperature and duration, as well as the concentration of the alloying elements in the alloy $[24,31,32]$. As the ratio of alloying elements is increased in steel and cast irons, the column-shaped structure decreases on the surfaces. Boride layers adhere better to the base material due to the column-shaped structure [33].

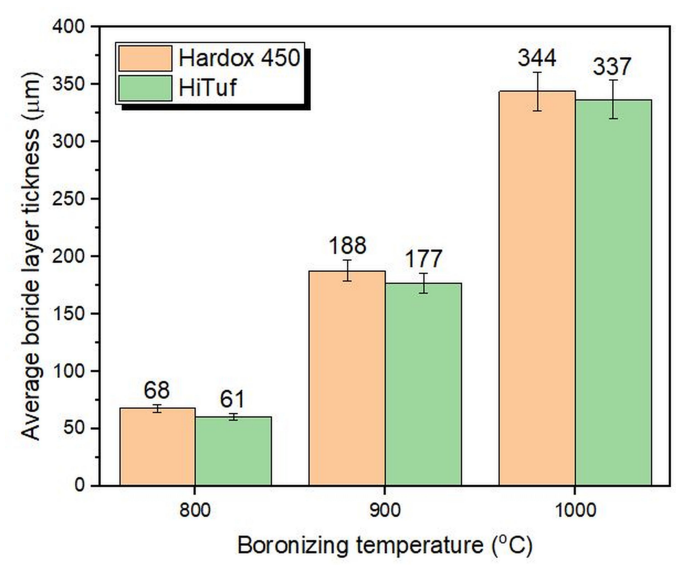

Figure 2: The effect of boriding temperature on boride layer depth in Hardox 450 and HiTuf steels.

Figure 3 shows the XRD patterns of Hardox 450 and HiTuf steels, which are borided at $900^{\circ} \mathrm{C}$ for $5 \mathrm{~h}$. XRD patterns of Hardox 450 steel show that $\mathrm{Fe}_{2} \mathrm{~B}$ and $\mathrm{FeB}$ boride layers are formed on the surface of the sample (Figure 3a). Furthermore, according to XRD results, only the $\mathrm{Fe}_{2} \mathrm{~B}$ boride layer has occurred in the HiTuf steel due to different chemical composition compared to Hardox 450 steel (Figure 3-b).
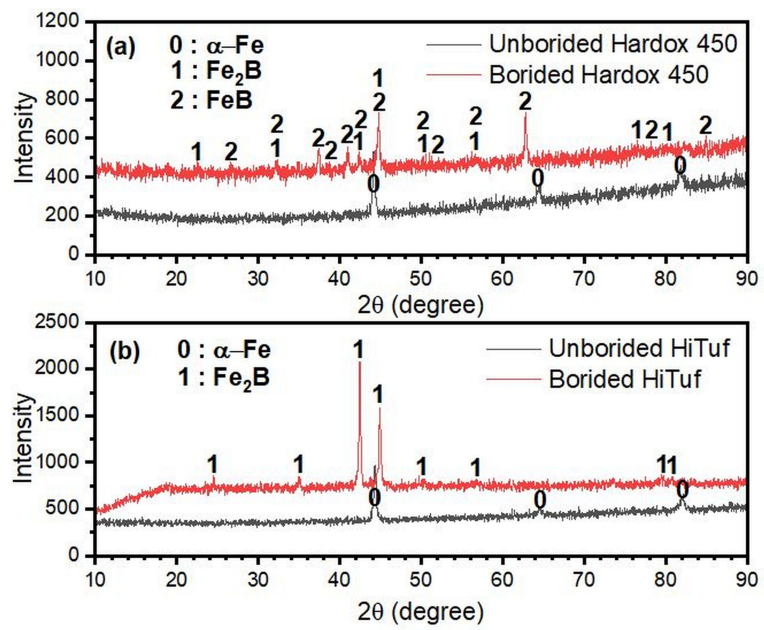

Figure 3: XRD patterns of unborided and borided samples; (a) Hardox 450, and (b) HiTuf steel.

Figure 4 indicates the SEM micrographs of the boride layers formed on the borided surfaces of Hardox 450 and Hituf steels borided at 800,900 , and $1000^{\circ} \mathrm{C}$ for $5 \mathrm{~h}$. Borided surfaces of Hardox 450 and HiTuf steels have three distinguishable zones (Figure 4a-4f). As seen in Figure 4, three distinct regions were identified on the surface of steels: (1) a layer containing boride phases (boride layer), 

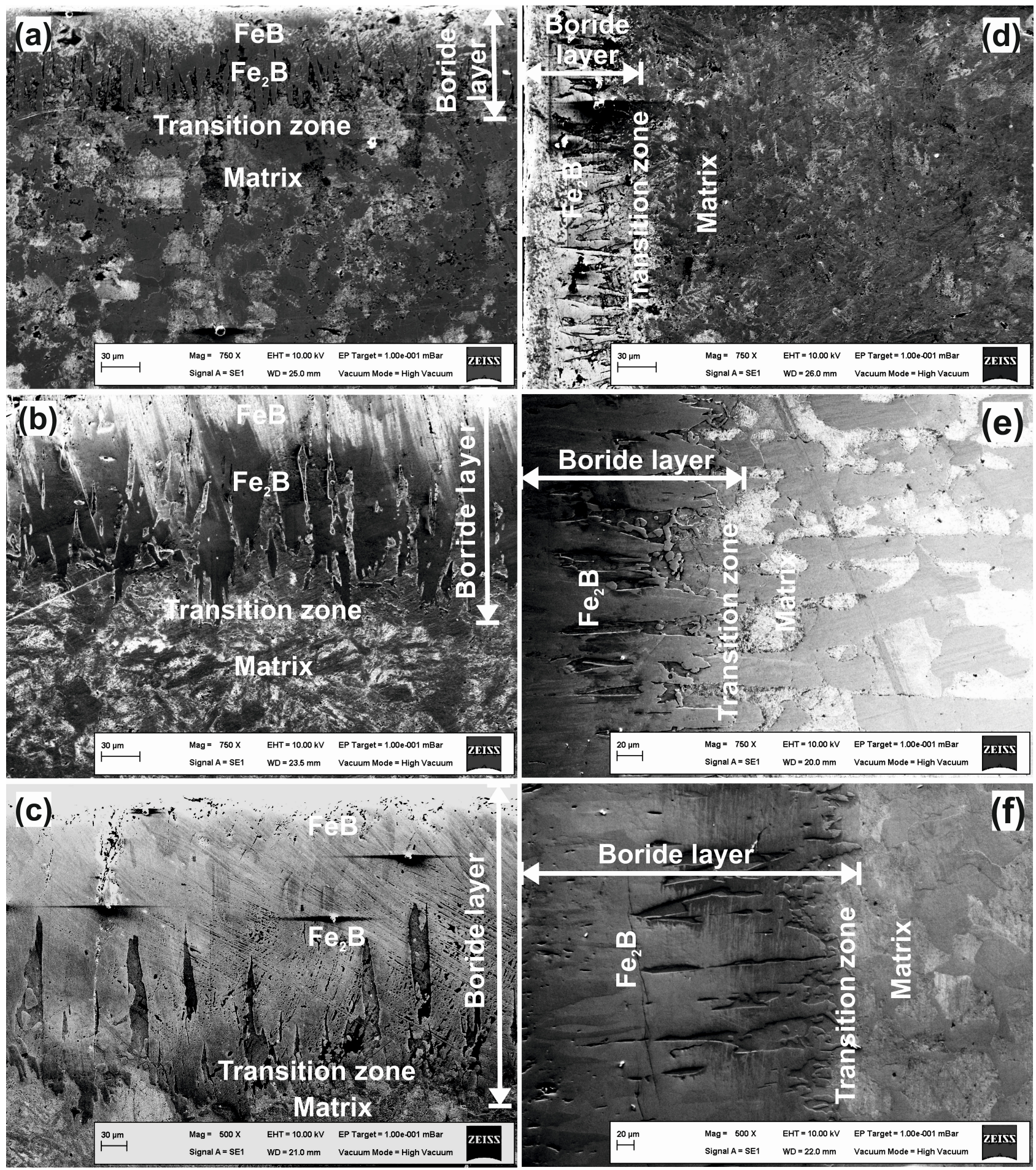

Figure 4: SEM microstructures of borided samples; (a) Hardox $450-800^{\circ} \mathrm{C}$, (b) Hardox $450-900^{\circ} \mathrm{C}$, (c) Hardox $450-1000^{\circ} \mathrm{C}$, (d) HiTuf-800 ${ }^{\circ} \mathrm{C}$, $€$ HiTuf- $900^{\circ} \mathrm{C}$, and (f) HiTuf- $1000^{\circ} \mathrm{C}$.

(2) a transition zone, and (3) a matrix not affected by boron diffusion. The boride layer consists of the outermost, a thin $\mathrm{FeB}$, and following, thick $\mathrm{Fe}_{2} \mathrm{~B}$ phases. The boride layer thicknesses have enhanced with increasing boriding temperature, and it has also occurred a grain growth in the column-shape grains of $\mathrm{Fe}_{2} \mathrm{~B}$ and $\mathrm{FeB}$ borides of samples with the increase of the boriding temperature (Figure 4a4f).

The micro-hardnesses of borided zones on the samples are presented in Figure 5. The Micro-hardnesses of 

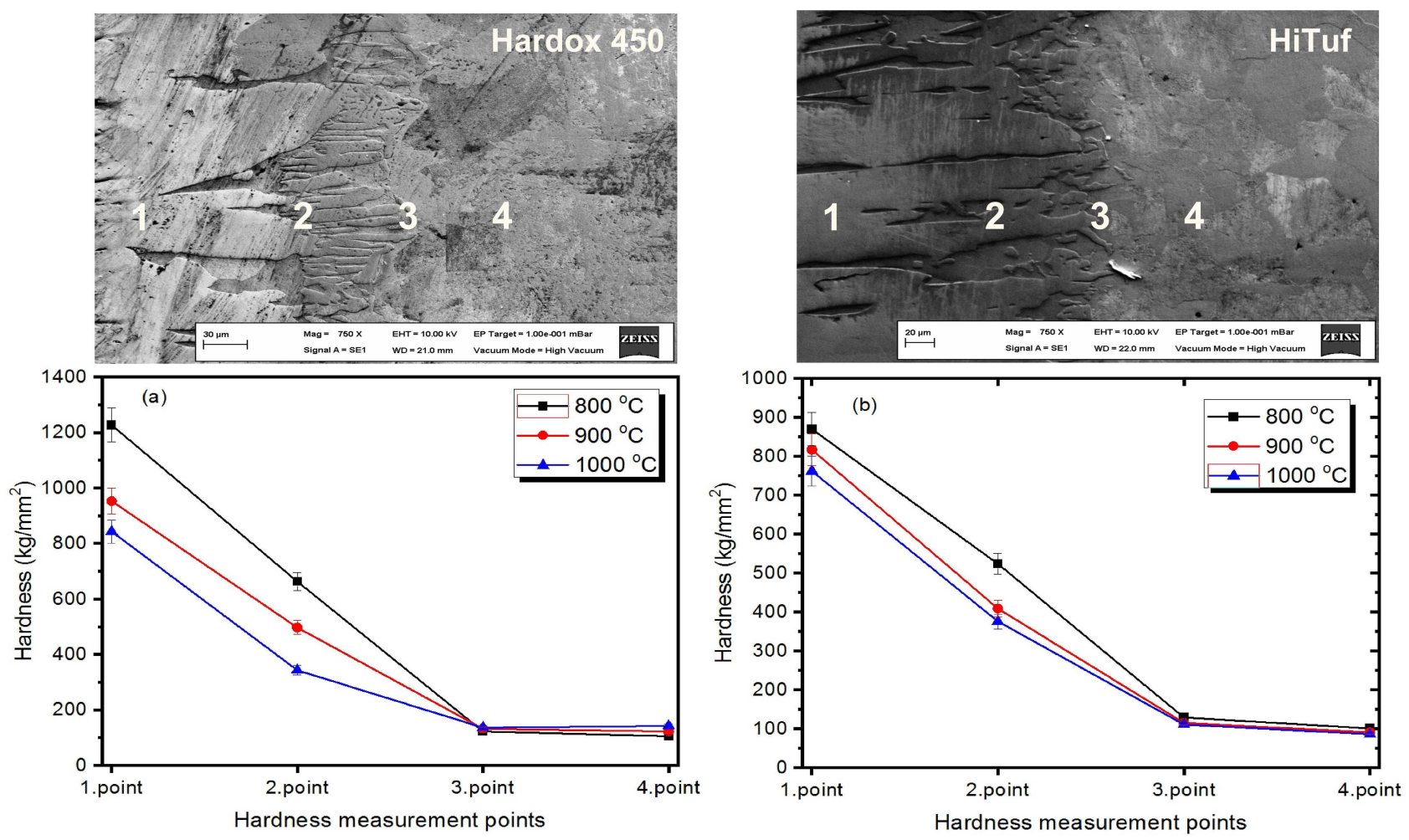

Figure 5: The change of hardness in the borided zones of the samples; (a) Hardox 450, and (b) HiTuf steel.

the samples were measured from boride layers, transition region, and matrix, respectively. The maximum microhardnesses for Hardox 450 steel borided at 800, 900, and $1000^{\circ} \mathrm{C}$ for $5 \mathrm{~h}$ were estimated as 1227,953 , and $843 \mathrm{~kg} / \mathrm{mm}^{2}$, respectively. Further, the maximum microhardnesses for HiTuf steel borided at 800,900 , and $1000^{\circ} \mathrm{C}$ for $5 \mathrm{~h}$ were measured as 870,817 , and $762 \mathrm{~kg} / \mathrm{mm}^{2}$, respectively. The reason for the low hardness is that the boriding temperature reaches the material and the recrystallization temperature. Here, the rearrangement and tempering of atoms are considered. On the other hand, the boride layer hardness decreases with an increasing boriding temperature due to grain growth, the embrittlement, and increasing thermal expansion of boride phases. When the hardness of the boride layer of Hardox 450 steel is compared to that of HiTuf steel, the boride layer hardness of Hardox 450 steel is $30 \%$ higher than that of Hituf steel because of the high content of $\mathrm{Cr}$ alloy element (Table 1). It is well known that $\mathrm{Cr}$ decreases forming of boride layer [34].

In our study, after the boriding treatment of Hardox 450 steel at different temperatures, the maximum hardness of the boride layer formed on the surface was found to be at $1227 \mathrm{~kg} / \mathrm{mm}^{2}$. Our results compared to similar studies in the literature, Mindivan notified that the maximum hardness of boride layer was $884 \mathrm{HV}$ after the boriding to Hardox 400 steel [2]. On the other hand, Kapcinska-
Popowska et al. reported that the maximum surface hardness of Hardox 450 steel measured as $1800 \mathrm{HV}$ by diffusion boriding process at $950^{\circ} \mathrm{C}$ for $4 \mathrm{~h} \mathrm{[30].} \mathrm{According} \mathrm{to}$ the findings of Kapcinska-Popowska et al., the boride layer hardness of Hardox 450 is higher than that of our results. However; in that study, it is notable that these researchers applied hardening to Hardox 450 steel in oil at $850^{\circ} \mathrm{C}$ immediately after the boriding treatment. This extra hardening process might cause an increase in the hardness of the boride layer [30].

Figure 6 shows graphs of friction coefficients (COFs) of unborided, and borided Hardox 450 and HiTuf steels recorded during wear tests under $30 \mathrm{~N}$ load at $25^{\circ} \mathrm{C}$. When the COFs of borided samples are compared to unborided samples, the COFs have decreased significantly in the borided samples (Figure 6). While the COF of the unborided Hardox 450 steel is 0.29 , this value decreases to 0.02 in borided Hardox 450 steel. Similarly, whereas the friction coefficient of unborided HiTuf steel is 0.16 , the COF of borided HiTuf steel has dropped to 0.04. The COFs of borided samples have reduced due to the excellent solid lubricant effect of $\mathrm{Fe}_{2} \mathrm{~B}$ and $\mathrm{FeB}$ phases formed on the surfaces of the samples by boriding treatment.

Bindal and Erdemir reported that they had the ultralow friction behavior of borided steel surfaces after flash annealing, and the friction coefficient of borided steel de- 

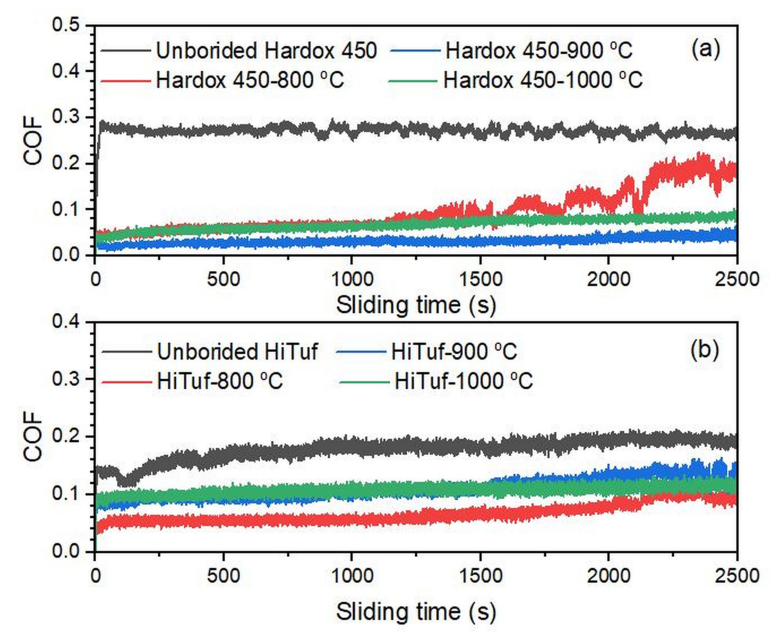

Figure 6: The change in the COFs of samples depending on sliding time; (a) Hardox 450, and (b) HiTuf steel.

creased from about 0.45 to 0.06 after flash annealing. In this study, flash annealing has been described as the process of exposing borided steel surfaces to high temperatures range of $600-800^{\circ} \mathrm{C}$ and then cooling to room temperature in open air. During this cooling, they also have been reported that $\mathrm{B}_{2} \mathrm{O}_{3}$ and $\mathrm{H}_{3} \mathrm{BO}_{3}$ films formed on the borided steel surfaces, and these films also were responsible for ultralow friction $[35,36]$. In our study, friction and wear experiment results show that it was parallel to the results of Bindal and Erdemir's study [35]. In our study, after boriding at 800,900 , and $1000^{\circ} \mathrm{C}$ for $5 \mathrm{~h}$, samples were removed from the oven and cooled in open air. This process is very similar to the flash annealing process in Bindal and Erdemir's study. Therefore, it is thought that the flash annealing process mentioned in these researchers' work may have occurred on the surfaces of our borided samples. As a result of this annealing process, it is thought that thin $\mathrm{B}_{2} \mathrm{O}_{3}$ and $\mathrm{H}_{3} \mathrm{BO}_{3}$ films may have formed on the surface of the borided Hardox 450 and HiTuf steels and may be the reason for ultra-low friction coefficients.

The wear rates of samples unborided, and borided at 800,900 , and $1000^{\circ} \mathrm{C}$ for $5 \mathrm{~h}$ are shown in Figure 7. The unborided Hardox 450 steel exhibited the highest wear rate. In contrast, the lowest wear rate occurred in the Hardox 450 samples borided at $900^{\circ} \mathrm{C}$ owing to toughness of the $\mathrm{Fe}_{2} \mathrm{~B}$ and $\mathrm{FeB}$ phases, and also, the lowest wear rate for Hituf steels came about in the samples borided at $800^{\circ} \mathrm{C}$. Due to the decrease in the hardness with the growth of crystals of borides formed at high boriding temperatures, there was an increase in wear rates in Hardox 450 borided at $1000^{\circ} \mathrm{C}$ as well as HiTuf steel borided at 900 and $1000^{\circ} \mathrm{C}$. It was reported that the hardness and thickness of the boride layers formed on the surface $[3,13,37]$ and also the other factors such as adhesion strength, elasticity modulus and fracture toughness [38] might have a considerable effect on wear resistance, and the increase in hardness and thickness could ensure greater resistance to abrasive wear. According to the results of the wear test, it has been shown that the wear resistance of the borided samples significantly enhanced by the boriding treatment due to having high toughness of the $\mathrm{Fe}_{2} \mathrm{~B}$ and $\mathrm{FeB}$ boride layers.

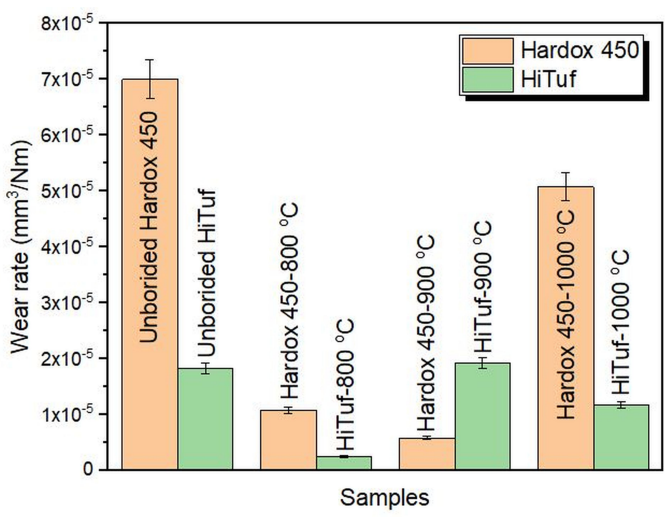

Figure 7: The change in wear rate of samples depending on boriding temperature.

The SEM micrographs of the worn surfaces of the unborided, and borided Hardox 450 and HiTuf steels are indicated in Figure 8. When the SEM images of the worn surfaces of both the Hardox 450 and HiTuf steels are examined, it shows that the wear occurring in the samples under $30 \mathrm{~N}$ load at $25^{\circ} \mathrm{C}$ mostly occurs with abrasive, and delamination wear mechanisms. The micrographs of wear tracks of borided Hardox 450 steel show that it was wear debris, spalling, microcutting, and microcracking (Figure 8a-8d). Furthermore, it created surface grooves, wear debris, and spalling on the worn surfaces of HiTuf steel (Figure 8e-8h). Due to probably the layer fatigue of hard $\mathrm{Fe}_{2} \mathrm{~B}$ and $\mathrm{FeB}$ phases on the surfaces, there have taken place cracks and cavities caused by delamination wear in the wear region of Hardox 450 and HiTuf steels. The different phases, such as $\mathrm{Fe}_{2} \mathrm{~B}$ and $\mathrm{FeB}$ formed on the surface, have different chemical compositions, thermal expansion coefficients, and mechanical behavior [3]. Hence, these hard phases, such as $\mathrm{Fe}_{2} \mathrm{~B}$ and $\mathrm{FeB}$, are separated during the sliding with the applied load, and delamination finally occurs. The microcracks develop under the surface of the sample and eventually spalling occurs, owing to surface roughness and repetitive forces acting on wear debris $[39,40]$. 


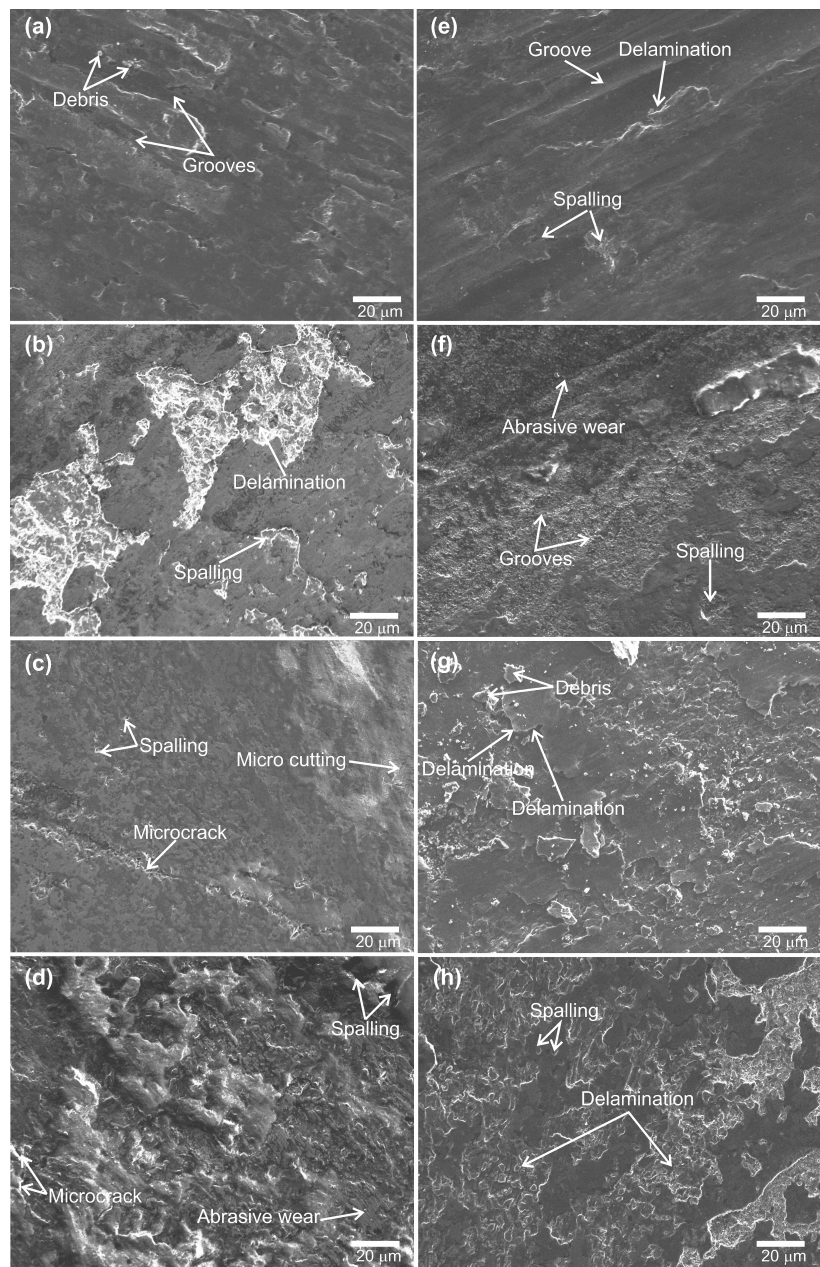

Figure 8: SEM wear surfaces micrographs of samples; (a) Unborided Hardox 450, (b) Hardox 450 borided at $800^{\circ} \mathrm{C}$, (c) Hardox 450 borided at $900^{\circ} \mathrm{C}$, (d) Hardox 450 borided at $1000^{\circ} \mathrm{C}$, (e) Unborided HiTuf, (f) HiTuf borided at $800^{\circ} \mathrm{C}$, (g) HiTuf borided at $900^{\circ} \mathrm{C}$, and (h) HiTuf borided at $1000^{\circ} \mathrm{C}$.

\section{Conclusions}

In the present study, the effect of different boriding temperatures on the structure, hardness, friction, and wear behavior of the boride layer formed on the surface of Hardox 450 and HiTuf steels was investigated. XRD results revealed that $\mathrm{Fe}_{2} \mathrm{~B}$ and $\mathrm{FeB}$ borides were formed on the surface of Hardox 450 steel by boriding treatment at different temperatures, and also, only $\mathrm{Fe}_{2} \mathrm{~B}$ boride occurred on the surface of HiTuf steel. Furthermore, it was determined that the thickness of the $\mathrm{FeB}$ and $\mathrm{Fe}_{2} \mathrm{~B}$ layers on the surfaces of Hardox 450 and HiTuf steels after the boriding treatment enhanced with increasing temperature, and the optimum thicknesses for Hardox 450 and HiTuf in terms of wear resistance were 188 and $177 \mu \mathrm{m}$, respectively. Besides, it was found that the boriding treatment increased the sur- face hardness of Hardox 450 and HiTuf steels, but the increase of the boriding temperature caused a decrease in hardness. According to our findings, the highest hardness values were determined in both steels at boriding temperature of $800^{\circ} \mathrm{C}$. The increase of the boriding temperature decreased the hardness of the boride layer owing to the grain growth of column-shaped boride crystals, the embrittlement, and the increasing of thermal expansion of boride phases. Additionally, the COFs decreased significantly in the borided samples. The COF of the unborided Hardox 450 steel was decreased from 0.29 to 0.02 by boriding treatment. Similarly, the friction coefficient of unborided HiTuf steel was diminished from 0.16 to 0.04 by boriding treatment. This decrease was due to the excellent solid lubricant effect of $\mathrm{Fe}_{2} \mathrm{~B}$ and $\mathrm{FeB}$ phases formed on the surfaces of the samples by boriding treatment. The lowest wear rate for Hardox 450 steel was obtained by boriding at 900 ${ }^{\circ} \mathrm{C}$, and $800{ }^{\circ} \mathrm{C}$ for HiTuf steel. The wear resistance of the borided samples considerably was enhanced by the boriding treatment due to having high toughness of the $\mathrm{Fe}_{2} \mathrm{~B}$ and $\mathrm{FeB}$ boride layers.

In conclusion, the results of this study have indicated that the wear resistance of Hardox 450 and HiTuf steels can be improved by pack-boriding treatment.

Acknowledgement: Authors thank HÜBAP (scientific research projects commission of Harran University, Sanliurfa, Turkey) for financial support of this study with project No: 15110 and K20004.

\section{References}

[1] Adamiak, M., J. Górka, and T. Kik. Comparison of abrasion resistance of selected constructional materials. The Journal of Achievements in Materials and Manufacturing Engineering. Vol. 37, No. 2, 2009, pp. 375-380.

[2] Mindivan, H. Effects of Combined Diffusion Treatments on the Wear Behaviour of Hardox 400 Steel. Procedia Engineering, Vol. 68, 2013, pp. 710-715.

[3] Günen, A. Properties and High Temperature Dry Sliding Wear Behavior of Boronized Inconel 718. Metallurgical and Materials Transactions. A, Physical Metallurgy and Materials Science, Vol. 51, No. 2, 2020, pp. 927-939.

[4] Günen, A., S. Bayar, and M. S. Karakaş. Effect of Different Arc Welding Processes on the Metallurgical and Mechanical Properties of Ramor 500 Armor Steel. Journal of Engineering Materials and Technology, Vol. 142, No. 2, 2020, p. 011010.

[5] Ulutan, M., O. N. Celik, H. Gasan, and U. Er. Effect of Different Surface Treatment Methods on the Friction and Wear Behavior of AISI 4140 Steel. Journal of Materials Science and Technology, Vol. 26, No. 3, 2010, pp. 251-257. 
[6] Tuckart, W., M. Gregorio, and L. lurman. Sliding wear of plasma nitrided AISI 405 ferritic stainless steel. Surface Engineering, Vol. 26, No. 3, 2010, pp. 185-190.

[7] Tabur, M., M. Izciler, F. Gül, and I. Karacan. Abrasive wear behavior of boronized AISI 8620 steel. Wear, Vol. 266, No. 11-12, 2009, pp. 1106-1112.

[8] Bejar, M. A., and E. Moreno. Abrasive wear resistance of boronized carbon and low-alloy steels. Journal of Materials Processing Technology, Vol. 173, No. 3, 2006, pp. 352-358.

[9] Selçuk, B., R. İpek, and M. B. Karamış. A study on friction and wear behaviour of carburized, carbonitrided and borided AISI 1020 and 5115 steels. Journal of Materials Processing Technology, Vol. 141, No. 2, 2003, pp. 189-196.

[10] Yılmaz, D., B. Aktaş, A. Çalık, and O. B. Aytar. Boronizing effect on the radiation shielding properties of Hardox 450 and Hardox HiTuf steels. Radiation Physics and Chemistry, Vol. 161, 2019, pp. 55-59.

[11] Tarakci, M., Y. Gener, and A. Calik. The pack-boronizing of pure vanadium under a controlled atmosphere. Applied Surface Science, Vol. 256, No. 24, 2010, pp. 7612-7618.

[12] Bektes, M., A. Calik, N. Ucar, and M. Keddam. Pack-boriding of Fe-Mn binary alloys: Characterization and kinetics of the boride layers. Materials Characterization, Vol. 61, No. 2, 2010, pp. 233239.

[13] Günen, A., E. Kanca, H. Çakir, M. S. Karakaş, M. S. Gök, Y. Küçük, and $M$. Demir. Effect of borotitanizing on microstructure and wear behavior of Inconel 625. Surface and Coatings Technology, Vol. 311, 2017, pp. 374-382.

[14] Arai, T. Thermochemical Surface Engineering of Steels. Chapter 2, Mittemeijer, E. J., and M. A. J. Somers, Eds, Elsevier, 2015, pp. 703-735.

[15] Xu, X. L., Z. W. Yu, and L. Y. Cui. Microstructure and properties of plasma nitrided layers on $\mathrm{Ni}$-based superalloy $\mathrm{Ni}-20 \mathrm{Cr}$. Materials Characterization, Vol. 155, 2019, p. 109798.

[16] Maragoudakis, N. E., G. Stergioudis, H. Omar, E. Pavlidou, and D. N. Tsipas. Boro-nitriding of steel US 37-1. Materials Letters, Vol. 57, No. 4, 2002, pp. 949-952.

[17] Ozdemir, O., M. Usta, C. Bindal, and A. H. Ucişik. Hard iron boride (Fe2B) on 99.97wt\% pure iron. Vacuum, Vol. 80, No. 11-12, 2006 , pp. 1391-1395.

[18] Özbek, I., and C. Bindal. Mechanical properties of boronized AISI W4 steel. Surface and Coatings Technology, Vol.154, No. 1, 2002, pp. 14-20.

[19] Uslu, İ., H. Cömert, M. İpek, O. Özdemir, and C. Bindal. Evaluation of borides formed on AISI P20 steel. Materials \& Design, Vol. 28, No. 1, 2005, pp. 55-61.

[20] Dybkov, V. I., W. Lengauer, and K. Barmak. Formation of boride layers at the $\mathrm{Fe}-10 \% \mathrm{Cr}$ alloy-boron interface. Journal of Alloys and Compounds, Vol. 398, No. 1-2, 2005, pp. 113-122.

[21] Calik, A., A. Duzgun, A. E. Ekinci, S. Karakas, and N. Ucar. Comparison of Hardness and Wear Behaviour of Boronized and Carburized AISI 8620 Steels. Acta Physica Polonica A, Vol. 116, No. 6, 2009, pp. 1029-1032.

[22] Kurt, B., L. Özdoğan, B. Güney, Ö. S. Bölükbaşı, and A. Günen. Characterization and wear behavior of TiBC coatings formed by thermo-reactive diffusion technique on AISI D6 steel. Surface and Coatings Technology, Vol. 385, 2020, p. 125332.

[23] Gunes, I., and I. Yıldız. Investigation of Adhesion and Tribological Behavior of Borided AISI 310 Stainless Steel. Matéria (Rio de Janeiro), Vol. 21, No. 1, 2016, pp. 61-71.
[24] Meriç, C., S. Şahin, B. Backir, and N. S. Köksal. Investigation of the boronizing effect on the abrasive wear behavior in cast irons. Materials \& Design, Vol. 27, No. 9, 2006, pp. 751-757.

[25] Sert, H., A. Can, H. Arıkan, B. Selçuk, and H. Toprak. Wear behavior of different surface treated cam spindles. Wear, Vol. 260, No. 9-10, 2006, pp. 1013-1019.

[26] Gunes, I. T. Investigation of tribological properties and characterization of borided AISI 420 and AISI 5120 steels. Transactions of the Indian Institute of Metals, Vol. 67, No. 3, 2014, pp. 359-365.

[27] Lee, S. Y., G. S. Kim, and B. S. Kim. Mechanical properties of duplex layer formed on AISI 403 stainless steel by chromizing and boronizing treatment. Surface and Coatings Technology, Vol. 177-178, 2004, pp. 178-184.

[28] Yan, P. X., Z. Q. Wei, X. L. Wen, Z. G. Wu, J. W. Xu, W. M. Liu, and J. Tian. Post boronizing ion implantation of $\mathrm{C} 45$ steel. Applied Surface Science, Vol. 195, No. 1-4, 2002, pp. 74-79.

[29] Kapcinska-Popowska, D., A. Pertek-Owsianna, A. Bartkowska, Bartkowski, D., and Przestacki, D. Influence of diffusion boriding and laser boriding on corrosion resistance Hardox 450 steel. Journal of Research and Applications in Agricultural Engineering, Vol. 59, No. 2, 2014, pp. 40-45.

[30] Kapcinska-Popowska, D., A. Pertek-Owsianna, and A. Bartkowska. Diffusion and laser boriding of Hardox 450 steel. Journal of Research and Applications in Agricultural Engineering, Vol. 60, 2015, pp. 40-42.

[31] Gök, M. S., Y. Küçük, A. Erdoğan, M. Öge, E. Kanca, and A. Günen. Dry sliding wear behavior of borided hot-work tool steel at elevated temperatures. Surface and Coatings Technology, Vol. 328, 2017, pp. 54-62.

[32] Taktak, S. Some mechanical properties of borided AISI H13 and 304 steels. Materials \& Design, Vol. 28, No. 6, 2007, pp. 18361843.

[33] Şen, S., I. Özbek, U. Şen, and C. Bindal. Mechanical behavior of borides formed on borided cold work tool steel. Surface and Coatings Technology, Vol. 135, No. 2-3, 2001, pp. 173-177.

[34] Calik, A., M. Simsek, M. S. Karakas, and N. Ucar. Effect of Boronizing on Microhardness and Wear Resistance of Steel AISI 1050 and Chilled Cast Iron. Metal Science and Heat Treatment, Vol. 56, No. 1-2, 2014, pp. 89-92.

[35] Bindal, C., and A. Erdemir. Ultralow friction behavior of borided steel surfaces after flash annealing. Applied Physics Letters, Vol. 68, No. 7, 1996, pp. 923-925.

[36] Erdemir, A., M. Halter, and G. R. Fenske. Preparation of ultralowfriction surface films on vanadium diboride. Wear, Vol. 205, No. 1-2, 1997, pp. 236-239.

[37] Kurt, B., Y. Küçük, and M. S. Gök. Microabrasion Wear Behavior of VC and CrC Coatings Deposited by Thermoreactive Diffusion Technique. Tribology Transactions, Vol. 57, No. 2, 2014, pp. 345352.

[38] Teker, T., and E. M. Karakurt. Characterization of the boron layer formed by pack boronizing of binary iron-niobium alloys. Materials Testing, Vol. 61, No. 9, 2019, pp. 875-879.

[39] Pauschitz, A., M. Roy, and F. Franek. Mechanisms of sliding wear of metals and alloys at elevated temperatures. Tribology International, Vol. 41, No. 7, 2008, pp. 584-602.

[40] Aktas, B., V. Balak, and C. Carboga. Dry Sliding Wear Behavior of Boron-Doped AISI 1020 Steels. Acta Physica Polonica A, Vol. 132, No. 3, 2017, pp. 455-457. 